\title{
Research Paper: The Effects of Succimer and Penicillamine on Acute Lead Poisoning Patients
}

\author{
Gholamali Dorooshi $^{1}$ O, Negar Molavi' ${ }^{1}$ Rokhsareh Meamar $^{1^{*}}$ Q, Akbar Hasanzadeh², Nastaran Eizadi-Mood ${ }^{1}$
}

1. Department of Clinical Toxicology, Isfahan Clinical Toxicology Research Center, Isfahan University of Medical Sciences, Isfahan, Iran.

2. Department of Epidemiology \& Biostatistics, Faculty of Health, Isfahan University of Medical Sciences, Isfahan, Iran.

\begin{tabular}{|c|c|}
\hline $\begin{array}{l}\text { Use your device to scan } \\
\text { and read the article online }\end{array}$ & $\begin{array}{l}\text { Citation Dorooshi G, Molavi N, Meamar R, Hasanzadeh A, Eizadi-Mood N. The Effects of Succimer and Penicillamine on } \\
\text { Acute Lead Poisoning Patients. International Journal of Medical Toxicology and Forensic Medicine. 2021; 11(3):33474. https:// } \\
\text { doi.org/10.32598/ijmtfm.v11i3.33474 }\end{array}$ \\
\hline a & d tei"https://doi.org/10.32598/ijmtfm.v11i3.33474 \\
\hline
\end{tabular}

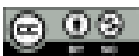

Article info:

Received: 24 Dec 2020

First Revision: 10 Jan 2021

Accepted: 27 Jan 2021

Published: 25 Aug 2021

\section{ABSTRACT}

Background: Lead poisoning was on the rise in recent years. There exists a lack of easy access to some of the main chelator drugs in developing countries. Thus, this study aimed to explore the comparative effects of Succimer and D-Penicillamine on acute lead poisoning patients from 2013 to 2018 .

Methods: This descriptive study was conducted in the Clinical Toxicology Department of Khorshid Hospital in Isfahan City, Iran. Adult patients with acute lead poisoning were included in the study. Patients in the 3 treatment groups of D-Penicillamine, D-Penicillamine with succimer, and succimer were compared concerning demographic characteristics as well as clinical and laboratory findings at admission time and two weeks later.

Results: In total, 163 patients were evaluated in this research. There was no significant difference between the treatment groups respecting improvement in clinical symptoms. The mean blood lead levels during hospitalization and two weeks after the treatment did not significantly differ between the three groups; however, there was a significant reduction in all study groups after two weeks of treatment $(\mathrm{P}<0.05)$. The mean white blood cell count was significantly lower only in the D-Penicillamine group two weeks after hospitalization $(\mathrm{P}<0.05)$. In the D-Penicillamine group, the mean platelet, hematocrit, and hemoglobin levels were significantly lower two weeks after hospitalization, although within the healthy range.

Conclusion: D-Penicillamine may be an acceptable chelator drug for treating patients with acute lead poisoning, especially in communities without access to drugs, like succimer.
D-Penicillamine, Succimer, Poisoning, Lead, Treatment

\section{* Corresponding Author:}

Rokhsareh Meamar, MD, Ph.D.

Address: Department of Clinical Toxicology, Isfahan Clinical Toxicology Research Center, Isfahan University of Medical Sciences, Isfahan, Iran. Tel: +98 (913) 3091206

E-mail:meamar@pharm.mui.ac.ir 


\section{Introduction}

$\mathbf{L}$

ead is among the oldest known toxins; lead poisoning is a dangerous environmental and occupational disease [1]. It is more common and severe in developing countries. In the past 6 years, we have encountered a high prevalence of lead poisoning in Iran among opium users, especially its oral consumption $[2,3]$. Numerous studies have investigated the potential association between blood lead levels and various diseases in children and adults [4, 5]. The level of lead in blood and tissues, as well as the duration of exposure, could determine its toxicity [5]. Acute lead poisoning in recent years in Iran has occurred following the oral consumption of opium; however, in other parts of the world, it is often generated after eating, inhaling, or injecting large amounts of lead [6].

In the central nervous system, lead causes changes in the cerebral microvascular system; accordingly, such alternations result in cerebral edema, increased intracranial pressure, and acute encephalopathy syndrome [1]. Peripheral neuropathy is the classic effect of lead poisoning in adults. In this disease, the motor nerves are more involved than the sensory nerves, the hands are more involved than the legs, and the extensors are more involved than the flexors. Additionally, in children, lead poisoning reduces the Intelligence Quotient (IQ) [5].

Preventive measures against lead poisoning include efforts to clear the environment and workplace of leadcontaining materials [1] and increase workplace ventilation $[7,8]$. Besides, the main treatment is based on using the chelating drugs, which bind to lead and excrete it from the body. Implementing pharmacotherapy and the choice of its type depends on the patient's age, clinical symptoms, and blood lead level [5]. The indications for chelator therapy in adult acute lead poisoning, include the clinical manifestations of target organ damage (neuropathy or nephropathy), and asymptomatic patients with blood lead levels above $70 \mu \mathrm{g} / \mathrm{dL}$ with a strongly positive history or biochemical signs of poisoning [9]. In patients whose blood lead levels are not immediately available, those with a positive history can undergo experimental chelator treatment, if presenting confirmatory laboratory tests [10]. Dimercaprol (British Anti Lewisite; $\mathrm{BAL}$ ) with CaNa2EDTA (injection) is recommended for severe poisoning (encephalopathy) or lead levels $>100$ $\mu \mathrm{g} / \mathrm{dL}$ and succimer (DMSA) (orally) for managing mild lead poisoning [5].

D-Penicillamine is a well-known lead chelator, used to be the first-line treatment in mild to moderate lead poi- soning; currently, with the availability of other drugs, it is only used to treat copper, mercury, and arsenic poisoning $[11,12]$. Succimer, compared with other suggested drugs in lead poisoning is a low-complication drug [13-15].

Considering the high prevalence of lead poisoning due to oral opium consumption, and the limited succimer availability in our country [3], D-Penicillamine is the only drug, i.e., widely available and inexpensive. It is used by physicians for treating lead poisoning. This study compared the effects of succimer and D-penicillamine on acute lead poisoning patients.

\section{Materials and Methods}

After obtaining the code of ethics for this descriptive study (IR.MUI.MED.REC.1398.488), the information related to all patients with acute lead poisoning was reviewed. For this purpose, we referred to the archives of Khorshid Hospital in Isfahan City, Iran, from 2013 to 2018.

The inclusion criteria included adult patients with acute lead poisoning; presenting one or more symptoms of intoxication, such as abdominal pain, constipation, headache, restlessness, memory and behavioral problems, tingling sensation in hands or feet, or blood lead levels $\geq 70 \mu \mathrm{g} / \mathrm{dL}$. Acute lead poisoning refers to the symptoms of poisoning that occur during the last 6 weeks following the contact with lead over the past year [5]. The exclusion criteria were patients' unwillingness to continue cooperation during treatment or at follow-up, presenting severe renal insufficiency, and elevated creatinine during treatment. Patients who had contraindications to using drugs, such as penicillin allergy, renal failure, and bone marrow diseases, etc. were excluded from the study. All demographic findings, including age, gender, clinical signs (fever, icter, illusions, delusions, skin rash, limb weakness, weak plantar reflex, convulsions, abdominal pain, constipation, nausea, vomiting, \& anorexia) spasm, vital signs, including systolic and diastolic blood pressure, heart rate, outcome and the duration of hospitalization, and laboratory data (i.e., BUN, Cr, Na, K, ALT, AST, blood analysis) were recorded.

The study patients were divided into 3 treatment groups, as follows: D-Penicillamine (250 mg every 6 hours orally for two weeks); D-Penicillamine (250 $\mathrm{mg}$ every 6 hours orally for two weeks) plus succimer (200 mg every 6 hours orally for two weeks); and succimer $(10 \mathrm{mg} / \mathrm{kg}$ for the first 5 days every 8 hours, then every 12 hours up to 14 days). 
The research patients were hospitalized in the poisoning ward until all symptoms were resolved. They were followed up for 4 weeks after discharge. The patients' blood lead levels were checked 3 weeks after discharge and their clinical symptoms were assessed. The demographic characteristics, clinical signs, and laboratory parameters of patients at admission and 3 weeks later were recorded in the data gathering form.

The obtained data were analyzed by SPSS. Descriptive data were reported using Mean $\pm \mathrm{SD}$, percentage, and absolute count. The collected data were analyzed using Chi-squared or Fisher's Exact test, Paired Samples t-test, and Analysis of Variance (ANOVA) At $\mathrm{P}<0.05$.

\section{Results}

In total, 163 patients were included in the study. Moreover, 93 patients received D-Penicillamine, 35 patients received D-Penicillamine plus succimer, and 35 patients only received succimer. Approximately $95 \%$ of the ex- plored patients were males. There was no significant difference in the frequency distribution of gender $(\mathrm{P}=0.84)$ and outcome $(\mathrm{P}=0.32)$ between the study groups. The explored patients were evaluated for clinical symptoms at admission. The most common condition observed among the patients was gastrointestinal symptoms (abdominal pain: $82.7 \%$ ) (Table 1).

Nausea and vomiting were significantly lower in the DPenicillamine group than the other two groups $(\mathrm{P}=0.01)$. The frequency of other symptoms was not significantly different between the research groups $(\mathrm{P}>0.05)$.

Mean age, the duration of hospitalization, mean blood pressure, and heart rate were not significantly different between the study groups. The age range of the study subjects was 14-79 years in the D-Penicillamine group, 26-64 years in the D-Penicillamine plus succimer group, and 30-74 years in the succimer group (Table 2).

Table 1. Epidemiological and clinical manifestations of the examined patients with acute lead poisoning

\begin{tabular}{|c|c|c|c|c|}
\hline \multirow{2}{*}{ Variables } & \multicolumn{3}{|c|}{ No. (\%) } & \multirow{2}{*}{$\begin{array}{c}\text { P (Be- } \\
\text { tween } \\
\text { Groups)* }\end{array}$} \\
\hline & D-Penicillamine & D-Penicillamine+Succimer & Succimer & \\
\hline Female & 4 (34.3) & $2(5.7)$ & $1(2.9)$ & \multirow[b]{2}{*}{0.84} \\
\hline Gender & 89 (95.7) & 33 (94.3) & 34 (97.1) & \\
\hline \multirow{2}{*}{ Outcome } & $91(97.8)$ & $35(100)$ & $35(100)$ & \multirow{2}{*}{0.33} \\
\hline & $2(2.2)$ & $0(0)$ & $0(0)$ & \\
\hline Abdominal pain & $74(79.6)$ & $32(91.4)$ & $27(77.1)$ & 0.23 \\
\hline Constipation & $32(34.4)$ & $9(25.7)$ & $14(40)$ & 0.44 \\
\hline Nausea \& vomiting & $17(18.3)$ & 15 (42.9) & $12(34.3)$ & 0.01 \\
\hline Anorexia & $12(12.9)$ & $1(2.9)$ & $4(11.4)$ & 0.17 \\
\hline Illusions \& delusions & $0(0)$ & $1(2.9)$ & $1(2.9)$ & 0.18 \\
\hline Weak plantar reflex & $34(36.6)$ & $16(45.7)$ & 15 (42.9) & 0.59 \\
\hline Spasm & $6(6.5)$ & $1(2.9)$ & $1(2.9)$ & 0.56 \\
\hline Fever & $2(2.02)$ & $0(0)$ & $1(2.9)$ & 0.47 \\
\hline Skin rash & $2(2.02)$ & $0(0)$ & $0(0)$ & 0.32 \\
\hline Limb weakness & $16(17.2)$ & $4(11.4)$ & $4(11.4)$ & 0.59 \\
\hline Icter & $2(2.2)$ & $1(2.9)$ & $0(0)$ & 0.47 \\
\hline Convulsions & $0(0)$ & $1(2.9)$ & $1(2.9)$ & 0.18 \\
\hline
\end{tabular}


Table 2. The Mean \pm SD age and duration of hospitalization and blood pressure in the research groups

\begin{tabular}{|c|c|c|c|c|}
\hline \multirow{2}{*}{ Variables } & \multicolumn{3}{|c|}{ Mean $\pm S D$} & \multirow{2}{*}{$\begin{array}{l}\text { P (Between } \\
\text { Group)* }\end{array}$} \\
\hline & D-Penicillamine & D-Penicillamine+Succimer & Succimer & \\
\hline Age (y) & $47.1 \pm 12.3$ & $42.8 \pm 9.5$ & $44.5 \pm 9.8$ & 0.13 \\
\hline Length of hospitalization (day) & $2.7 \pm 1.1$ & $3.4 \pm 2.9$ & $3.1 \pm 2.7$ & 0.16 \\
\hline Systolic blood pressure (mm Hg) & $131.3 \pm 22.7$ & $128.9 \pm 15.5$ & $132.3 \pm 18.4$ & 0.79 \\
\hline Diastolic blood pressure (mm Hg) & $83.7 \pm 13.2$ & $80.6 \pm 14.4$ & $82.6 \pm 10.6$ & 0.51 \\
\hline Heart rate/minute & $84.3 \pm 14.2$ & $84.9 \pm 12.9$ & $87.4 \pm 14.2$ & 0.58 \\
\hline
\end{tabular}

* At the level of $5 \%$ one-way ANOVA

The collected results revealed no significant difference in improving blood lead levels between the treatment groups. Furthermore, the mean Blood Lead Levels (BLL) at admission $(\mathrm{P}=0.38)$ and three weeks after admission ( $\mathrm{P}=0.32)$ were not significantly different between the 3 groups; however, in all study groups, 3 weeks after admission, there was a significant decrease in BLL, compared with the admission time $(\mathrm{P}<0.001)$ (Table 3$)$.

In laboratory parameters, in all study groups, the mean blood urea nitrogen was significantly lower 3 weeks after admission, compared to the time of admission $(\mathrm{P}<0.05)$. The mean white blood cells only in the D-Penicillamine group, 3 weeks after admission, was significantly lower than the admission time $(\mathrm{P}=0.01)$. No other significant differences were observed in any groups regarding the other clinical parameters.

The obtained results suggested that the mean platelets $(\mathrm{P}<0.001)$, hematocrit $(\mathrm{P}=0.002)$, and hemoglobin $(\mathrm{P}<0.001)$ in the D-Penicillamine group, 3 weeks after admission, were significantly lower than that of the time of admission. No significant difference was observed among the other blood parameters in the study groups (Table 4).

\section{Discussion}

The current retrospective study compared the effects of D-Penicillamine and Succimer chelators on the clinical and laboratory symptoms of patients with acute lead poisoning before and after chelator therapy. The obtained results suggested no significant difference between the treated groups concerning the improvement of clinical symptoms; all three treatment approaches were equally effective. Respecting laboratory parameters, in the DPenicillamine group, the mean value of blood urea nitrogen, white blood cells, platelets, hematocrit, and hemoglobin indicated a significant decrease after three weeks; however, all of them were within the normal range and required no intervention. Several reports of life-threatening adverse reactions, such as bone marrow and kidney dysfunction leading to leucopenia, thrombocytopenia, and skin complications, have led to D-Penicillamine as a third-line drug in treating lead poisoning $[10,16,17]$; thus, they should be used with caution. Despite its risks, this drug with low-dose $(15 \mathrm{mg} / \mathrm{kg} /$ day $)$ remains desirable in mild to moderate lead poisoning in children and adults $[18,19]$.

Concerning D-penicillamine, Paeezi et al. and Farzaneh et al. suggested that D-penicillamine may be an acceptable alternative treatment for lead poisoning in

Table 3. Comparing the Mean \pm SD blood lead levels between the research groups at admission and 3 weeks later

\begin{tabular}{|c|c|c|c|c|}
\hline \multirow{2}{*}{$\begin{array}{c}\text { BLL }(\mu \mathrm{g} / \mathrm{dL}) \\
\text { Time }\end{array}$} & \multicolumn{3}{|c|}{ Mean $\pm S D$} & \multirow{2}{*}{$\begin{array}{l}\text { P (Within } \\
\text { Group)* }\end{array}$} \\
\hline & D-Penicillamine & D-Penicillamine+Succimer & Succimer & \\
\hline At admission & $89.1 \pm 27.1$ & $87.4 \pm 20.8$ & $95.5 \pm 29.5$ & 0.38 \\
\hline Three weeks later & $54.6 \pm 16.8$ & $53.4 \pm 17.6$ & $58.9 \pm 16.1$ & 0.32 \\
\hline P (between group) & $<0.001^{*}$ & $<0.001^{*}$ & $<0.001^{*}$ & \\
\hline
\end{tabular}


Table 4. Comparing the mean laboratory data between the treated groups

\begin{tabular}{|c|c|c|c|c|c|}
\hline \multirow{2}{*}{ Variables } & \multirow{2}{*}{ Time } & \multicolumn{3}{|c|}{ Mean士SD } & \multirow{2}{*}{$\begin{array}{c}\text { P } \\
\text { (Between } \\
\text { Group)* }^{*}\end{array}$} \\
\hline & & D-Penicillamine & D-Penicillamine With Succimer & Succimer & \\
\hline \multirow[b]{2}{*}{$\mathrm{BUN}(\mathrm{mg} / \mathrm{dL})$} & At admission & $16.3 \pm 5.9$ & $14.6 \pm 5.7$ & $17.1 \pm 7.9$ & 0.28 \\
\hline & $\begin{array}{l}\text { Three weeks after } \\
\text { admission }\end{array}$ & $14.03 \pm 6.5$ & $10.4 \pm 3.5$ & $11.2 \pm 3.1$ & 0.07 \\
\hline \multicolumn{2}{|c|}{$\mathrm{P}^{* *}$ (within groups) } & 0.02 & 0.005 & 0.03 & \\
\hline \multirow[b]{2}{*}{$\mathrm{Cr}(\mathrm{mg} / \mathrm{dL})$} & At admission & $1.1 \pm 0.1$ & $1.1 \pm 0.2$ & $0.9 \pm 0.04$ & 0.70 \\
\hline & $\begin{array}{l}\text { Three weeks after } \\
\text { admission }\end{array}$ & $1.2 \pm 0.4$ & $0.8 \pm 0.05$ & $0.8 \pm 0.04$ & 0.55 \\
\hline \multicolumn{2}{|c|}{$\mathrm{P}^{* *}$ (within groups) } & 0.32 & 0.30 & 0.19 & \\
\hline \multirow[b]{2}{*}{ ALT (mg/dL) } & At admission & $37.5 \pm 4.1$ & $39.3 \pm 4.5$ & $42.8 \pm 6.8$ & 0.79 \\
\hline & $\begin{array}{l}\text { Three weeks after } \\
\text { admission }\end{array}$ & $36.7 \pm 5.5$ & $30.4 \pm 6.4$ & $32.3 \pm 8.8$ & 0.77 \\
\hline \multicolumn{2}{|c|}{$\mathrm{P} * *$ (within groups) } & 0.94 & 0.23 & 0.22 & \\
\hline \multirow{2}{*}{ AST (mg/dL) } & At admission & $44.6 \pm 3.1$ & $43.6 \pm 3.9$ & $45.5 \pm 5.8$ & 0.96 \\
\hline & $\begin{array}{c}\text { Three weeks after } \\
\text { admission }\end{array}$ & $36.8 \pm 4.8$ & $33.3 \pm 3.4$ & $33.8 \pm 5.9$ & 0.85 \\
\hline \multicolumn{2}{|c|}{$\mathrm{P}^{* *}$ (within groups) } & 0.15 & 0.14 & 0.11 & \\
\hline \multirow{2}{*}{$\mathrm{Na}(\mathrm{meq} / \mathrm{L})$} & At admission & $136.7 \pm 3.1$ & $136.7 \pm 3.6$ & $136.8 \pm 2.9$ & 0.98 \\
\hline & $\begin{array}{c}\text { Three weeks after } \\
\text { admission }\end{array}$ & $135.5 \pm 3.6$ & $134.5 \pm 3.9$ & $134.1 \pm 4.7$ & 0.27 \\
\hline \multicolumn{2}{|c|}{$\mathrm{P}^{* *}$ (within groups) } & 0.12 & 0.13 & 0.14 & \\
\hline \multirow{2}{*}{$\mathrm{K}$ (meq/L) } & At admission & $4.1 \pm 0.5$ & $4.1 \pm 0.5$ & $4 \pm 0.5$ & 0.29 \\
\hline & $\begin{array}{c}\text { Three weeks after } \\
\text { admission }\end{array}$ & $3.9 \pm 0.4$ & $4.04 \pm 0.5$ & $3.9 \pm 0.6$ & 0.46 \\
\hline \multicolumn{2}{|c|}{$\mathrm{P} * *$ (within groups) } & 0.10 & 0.12 & 0.74 & \\
\hline \multirow[b]{2}{*}{$\mathrm{RBC}(\mathrm{M} / \mu \mathrm{L})$} & At admission & $4.2 \pm 0.9$ & $3.7 \pm 0.6$ & $4.3 \pm 0.9$ & 0.13 \\
\hline & $\begin{array}{l}\text { Three weeks after } \\
\text { admission }\end{array}$ & $3.9 \pm 0.1$ & $3.7 \pm 0.1$ & $4.2 \pm 0.3$ & 0.14 \\
\hline \multicolumn{2}{|c|}{$\mathrm{P}^{* *}$ (within groups) } & 0.09 & 0.33 & 0.82 & \\
\hline \multirow[b]{2}{*}{$\mathrm{WBC}(\mathrm{K} / \mu \mathrm{L})$} & At admission & $8.9 \pm 2.9$ & $9.8 \pm 2.9$ & $10 \pm 3.3$ & 0.14 \\
\hline & $\begin{array}{l}\text { Three weeks after } \\
\text { admission }\end{array}$ & $8.3 \pm 2.6$ & $8.9 \pm 2.7$ & $9.9 \pm 3.7$ & 0.06 \\
\hline \multicolumn{2}{|c|}{$\mathrm{P} * *$ (within groups) } & 0.01 & 0.14 & 0.51 & \\
\hline \multirow[b]{2}{*}{$\mathrm{MCV}(\mathrm{FL})$} & At admission & $85.3 \pm 6.9$ & $86 \pm 4.1$ & $85.5 \pm 6.9$ & 0.88 \\
\hline & $\begin{array}{c}\text { Three weeks after } \\
\text { admission }\end{array}$ & $86.1 \pm 6.8$ & $87.3 \pm 6.02$ & $84.3 \pm 7.6$ & 0.38 \\
\hline \multicolumn{2}{|c|}{$\mathrm{P}^{* *}$ (within groups) } & 0.08 & 0.13 & 0.88 & \\
\hline \multirow[b]{2}{*}{$\mathrm{MCH}(\mathrm{PG})$} & At admission & $27.8 \pm 3.8$ & $28.4 \pm 2.8$ & $28.3 \pm 2.9$ & 0.64 \\
\hline & $\begin{array}{c}\text { Three weeks after } \\
\text { admission }\end{array}$ & $27.9 \pm 3.2$ & $27.9 \pm 2.1$ & $27.4 \pm 3.7$ & 0.77 \\
\hline \multicolumn{2}{|c|}{$\mathrm{P}^{* *}$ (within groups) } & 0.74 & 0.60 & 0.66 & \\
\hline
\end{tabular}




\begin{tabular}{|c|c|c|c|c|c|}
\hline \multirow{2}{*}{ Variables } & \multirow{2}{*}{ Time } & \multicolumn{3}{|c|}{ Mean $\pm S D$} & \multirow{2}{*}{$\begin{array}{c}\text { P } \\
\text { (Between } \\
\text { Group)* }^{*}\end{array}$} \\
\hline & & D-Penicillamine & D-Penicillamine With Succimer & Succimer & \\
\hline \multirow{2}{*}{ RDW (\%) } & At admission & $15.7 \pm 2.7$ & $15.9 \pm 2.5$ & $16.03 \pm 2.2$ & 0.81 \\
\hline & $\begin{array}{l}\text { Three weeks after } \\
\text { admission }\end{array}$ & $15.9 \pm 2.5$ & $16.6 \pm 2.9$ & $16.6 \pm 2.5$ & 0.48 \\
\hline \multicolumn{2}{|c|}{$\mathrm{P}^{* *}$ (within groups) } & 0.24 & 0.07 & 0.23 & \\
\hline \multirow{2}{*}{$\mathrm{PLT}(\mathrm{K} / \mu \mathrm{L})$} & At admission & $245.9 \pm 87.4$ & $243.1 \pm 72.9$ & $256.9 \pm 65.4$ & 0.79 \\
\hline & $\begin{array}{l}\text { Three weeks after } \\
\text { admission }\end{array}$ & $226.03 \pm 84.9$ & $243.4 \pm 65.7$ & $236.1 \pm 69.9$ & 0.63 \\
\hline \multicolumn{2}{|c|}{$\mathrm{P}^{* *}$ (within groups) } & $<0.001$ & 0.94 & 0.27 & \\
\hline \multirow{2}{*}{ HCT (\%) } & At admission & $35.1 \pm 5.5$ & $32.6 \pm 4.7$ & $35.9 \pm 7.1$ & 0.06 \\
\hline & $\begin{array}{l}\text { Three weeks after } \\
\text { admission }\end{array}$ & $33.3 \pm 5.8$ & $32.9 \pm 4.3$ & $34.4 \pm 4.04$ & 0.64 \\
\hline \multicolumn{2}{|c|}{$\mathrm{P}^{* *}$ (within groups) } & 0.002 & 0.73 & 0.82 & \\
\hline \multirow{2}{*}{$\mathrm{Hb}(\mathrm{g} \backslash \mathrm{dl})$} & At admission & $11.5 \pm 2.1$ & $10.7 \pm 1.8$ & $11.8 \pm 2.6$ & 0.09 \\
\hline & $\begin{array}{l}\text { Three weeks after } \\
\text { admission }\end{array}$ & $10.8 \pm 2.1$ & $10.6 \pm 1.6$ & $11.3 \pm 1.7$ & 0.51 \\
\hline \multicolumn{2}{|c|}{$\mathrm{P}^{* *}$ (within groups) } & $<0.001$ & 0.21 & $>0.05$ & \\
\hline One-way AI & VA. & & & $\begin{array}{l}\text { International Jourr } \\
\text { Medical Toxicolo }\end{array}$ & Forensic Medicine \\
\hline
\end{tabular}

Aspartate transaminase (AST); Alanine transaminase (ALT); Creatinine (Cr); Blood Urea Nitrogen (BUN); Red Blood Cell (RBC); White Blood Cell (WBC); Mean Corpuscular Hemoglobin (MCH); Mean Corpuscular Volume (MCV); Red Blood Cell Distribution Width (RDW); Hematocrit (HCT); Hemoglobin (Hb); Platelets (PLT)

adults; it has no serious adverse effects. Therefore, using this drug can be beneficial, especially in cases with a high prevalence of lead poisoning and limited access to other antidotes [20,21]. In a study on 84 lead-poisoned patients treated with D-Penicillamine, Shannon et al. reported that in one-third of the patients, complications, such as transient leucopenia, thrombocytopenia, rash, enuresis, and abdominal pain were observed [19].

In another study, however, Shannon observed fewer adverse effects, including leukopenia and rash in children with lead poisoning at reduced doses of D-Penicillamine $(15 \mathrm{mg} / \mathrm{kg} / \mathrm{dose})$. Additionally, they detected no transient thrombocytopenia, enuresis, and abdominal pain. This finding suggests that adverse effects may be declined by reducing the dose of D-Penicillamine. It has been performed in children; thus, the results may not be valid for adults [22]. However, their obtained results were consistent with those of the present study, i.e., a turning point in expanding the age range of the use of D-Penicillamine for treating lead poisoning from children to adults.

Furthermore, in the other two groups (D-Penicillamine plus succimer $\&$ succimer groups), the mean blood urea nitrogen significantly decreased after 3 weeks without any requirement for intervention. A review study on 912 patients treated with succimer revealed that most patients with symptoms recovered to some extent after two days of treatment, with only a transient increase in transaminase activity occurring in $>60 \%$ of the patients during treatment, which had no significant clinical consequences [14]. These results were consistent with those of the present study. Moreover, in that study, skin reactions occurred in approximately $6 \%$ of the patients and the urinary excretion of copper and zinc also increased; however, it did not reach a clinically significant level [14]. Some researchers believed that neutropenia, abdominal cramps, nausea and vomiting, eosinophilia, and severe mucocutaneous reactions are other adverse effects of this drug. Therefore, using this drug should be discontinued if they occur $[10,13]$.

\section{Conclusion}

The obtained data indicated no significant difference between the study treatment groups concerning improvement in clinical symptoms. D-Penicillamine may be an acceptable and useful chelator for treating patients 
with acute lead poisoning, especially in communities that have no access to other drugs, like succimer.

\section{Ethical Considerations}

\section{Compliance with ethical guidelines}

All procedures involving the human participant were following the ethical standards of the institutional and or national research committee, the 1964 Helsinki Declaration, and its later amendments or comparable ethical standards. Private information, including name, surname, and burial permit was removed from the datasheet to comply with ethical concerns (IR.MUI.MED. REC.1398.488).

\section{Funding}

The paper was extracted from the MD thesis of Negar Molavi that was supported financially by the Isfahan University of Medical sciences.

\section{Author's contributions}

Conceptualization and Supervision: Gholmali Dorooshi, Rokhsareh Meamar, and Nastaran EizadiMood; Methodology: Gholmali Dorooshi; Investigation, Writing - original draft, and Writing - review \& editing: All authors; Data Collection: Negar molavi; Data analysis: Akbar hazsanzadh; Funding acquisition and resources: Gholmali Dorooshi.

\section{Conflict of interest}

The authors declared no conflicts of interest.

\section{Acknowledgments}

We would like to thank Toxicology Department Personnel for their encouragement through this work.

\section{References}

[1] Needleman H. Lead poisoning. Annu Rev Med. 2004; 55:209-22. [DOI:10.1146/annurev.med.55.091902.103653] [PMID]

[2] Mostafazadeh B, Shadnia S, Tavakkoli MA, Vishteh HR. Evaluation of blood lead level in methamphetamine users in Tehran. Subst Abuse Treat Prev Policy. 2017; 12(1):2. [DOI:10.1186/s13011-017-0088-3] [PMID] [PMCID]

[3] Ghane T, Zamani N, Hassanian-Moghaddam H, Beyrami A, Noroozi A. Lead poisoning outbreak among opium users in the Islamic Republic of Iran, 2016-2017. Bull World Health Organ. 2018; 96(3):165-172. [DOI:10.2471/BLT.17.196287] [PMID] [PMCID]

[4] Farhat AS, Parizadeh SM, Balali M, Khademi GR. Comparison of blood lead levels in 1-7 year old children with and without seizure. Neurosciences. 2005; 10(3):210-2 . [PMID]

[5] Nelson LS, Howland MA, Lewin NA, Smith SW, Goldfrank LR, Hoffman RS. Goldfrank's toxicologic emergencies. $11^{\text {th }}$ ed. New York: McGraw-Hill Companies; 2019. https:// www.amazon.com/Goldfranks-Toxicologic-EmergenciesEleventh-Nelson/dp/1259859614

[6] Zamani N, Mehrpour O, Hassanian-Moghaddam H, Jalali M, Amirabadizadeh A, Samie S, et al. A preliminary report on the largest ongoing outbreak of lead toxicity in Iran. Sci Rep. 2020 16; 10(1):11797. [DOI:10.1038/s41598-020-64859-8] [PMID] [PMCID]

[7] Gagas DF. Characterization of contaminants on firefighter" s protective equipment a firefighter's potential exposure to heavy metals during a structure fire [MSc. thesis]. United States: Eastern Kentucky University; 2015. https://encompass.eku.edu/etd/261/

[8] Parada C. An analysis of inorganic lead surface contamination and employee cross-contamination in a precious metal assay laboratory [MSc. thesis]. United States: Montana Tech of the University of Montana; 2011. https:// www.proquest. com/openview/5f2f82068ab42b4d516610c7fb7f7d3a/1?pqorigsite $=$ gscholar\&cbl $=18750$

[9] Dapul H, Laraque D. Lead poisoning in children. Adv Pediatr. 2014; 61(1):313-33. [DOI:10.1016/j.yapd.2014.04.004] [PMID]

[10] Chandran L, Cataldo R. Lead poisoning: Basics and new developments. Pediatr Rev. 2010; 31(10):399-405. [DOI:10.1542/ pir.31-10-399] [PMID]

[11] Kosnett MJ. Unanswered questions in metal chelation. J Toxicol Clin Toxicol. 1992; 30(4):529-47. [DOI:10.3109/15563659209017939] [PMID]

[12] Henretig F. Lead poisoning prevention, not chelation (commentary). J Toxicol Clin Toxicol. 2001; 39(7):659-60. [DOI:10.1081/CLT-100108505] [PMID]

[13] Bradberry S, Vale A. A comparison of sodium calcium edetate (edetate calcium disodium) and succimer (DMSA) in the treatment of inorganic lead poisoning. Clin Toxicol. 2009; 47(9):841-58. [DOI:10.3109/15563650903321064] [PMID]

[14] Bradberry S, Vale A. Dimercaptosuccinic acid (succimer; DMSA) in inorganic lead poisoning. Clin Toxicol. 2009; 47(7):617-31. [DOI:10.1080/15563650903174828] [PMID]

[15] Maiorino RM, Bruce DC, Aposhian HV. Determination and metabolism of dithiol chelating agents: VI. Isolation and identification of the mixed disulfides of meso-2, 3-dimercaptosuccinic acid with L-cysteine in human urine. Toxicol Appl Pharmacol. 1989; 97(2):338-49. [DOI:10.1016/0041-008X(89)90338-4]

[16] Woolf AD, Goldman R, Bellinger DC. Update on the clinical management of childhood lead poisoning. Pediatr Clin North Am. 2007; 54(2):271-94. [DOI:10.1016/j.pcl.2007.01.008] [PMID]

[17] American Academy of Pediatrics Committee on Environmental Health. lead exposure in children: Prevention, detection, and management. Pediatrics. 2006; 116(4):1036-46. [DOI:10.1542/peds.2005-1947] [PMID] 
[18] Kianoush S, Sadeghi M, Balali-Mood M. Recent advances in the clinical management of lead poisoning. Acta Med Iran. 2015; 53(6):327-36. [PMID]

[19] Shannon MW, Townsend MK. Adverse effects of reduceddose d-penicillamine in children with mild-to-moderate lead poisoning. Ann Pharmacother. 2000;34(1):15-8. [DOI:10.1345/ aph.19084] [PMID]

[20] Paeezi M, Zamani N, Hassanian-Moghaddam H, Shadnia $\mathrm{S}$, Zamani N, Chaleshi V, et al. Treatment of adult lead poisoning with D-penicillamine. Drug Metab Pers Ther. 2019; 34(2). [DOI:10.1515/dmpt-2019-0003] [PMID]

[21] Farzaneh E, Habibzadeh A, Mehrpour O. Lead toxicity among oral opium addicts with abdominal pain: A case series of 17 cases. Indian J Forensic Med Toxicol. 2017; 11(2):22-5. [DOI:10.5958/0973-9130.2017.00057.3]

[22] Shannon M, Graef J, Lovejoy FH Jr. Efficacy and toxicity of D-penicillamine in low level lead poisoning. J Pediatr. 1988; 112(5):799-804. [DOI:10.1016/S0022-3476(88)83212-8] 